\title{
Penggunaan Metode Student Team Achievement Division untuk Meningkatkan Motivasi Belajar Siswa pada Konsep Menghitung Luas Segitiga Kelas IV SD
}

\author{
Rodinah \\ SD Negeri 1 Dermaji \\ Karangjambu, Dermaji, Kec. Lumbir, Kabupaten Banyumas, Jawa Tengah \\ Email: bdmartono7@gmail.com
}

\begin{abstract}
Abstrak
Tujuan Penelitian ini adalah (1) menganalisis dampak penggunaan metode Student Team Achievement Division (STAD) dapat meningkatkan motivasi belajar siswa tentang konsep menghitung luas segitiga di kelas IV SD Negeri 1 DermajiKecamatan LumbirKabupaten Banyumas. (2) menganalisis dampak penggunaan metode Student Team Achievement Division (STAD) dapat meningkatkan hasil belajar siswa tentang konsep menghitung luas segitiga di kelas IV SD Negeri 1 DermajiKecamatan Banyumas Kabupaten Banyumas. Prosedur PTK meliputi empat langkah penelitian yaitu perencanaan, pelaksanaan, observasi dan refleksi dalam pelaksanaannya sebanyak dua siklus. Hasil penelitian ini dapat disimpulkan sebagai berikut: (1) penggunaan metode STAD dalam pembelajaran matematika tentang menghitung luas segitiga dapat meningkatkan motivasi belajar siswa kelas IV SD Negeri 1 DermajiKecamatan Banyumas Kabupaten Banyumas dengan kenaikan dari 10 siswa menjadi 22 siswa atau 50.00\%. (2) Dengan penggunaan alat peraga gambar dapat meningkatkan hasil belajar siswa kelas IV SD Negeri 1 Dermajidengan rata-rata dari awal pembelajaran sampai siklus II yaitu 49,79 menjadi 75,63 naik 86,67 dan ketuntasan belajar dari 8 siswa menjadi 18 siswa kemudian naik menjadi 23 siswa dari 24 siswa secara keseluruhan. Sehingga dalam kesimpulan penelitian ini adalah (1) Penggunaan metode STAD dapat meningkatkan motivasi belajar siswa di kelas IV SD Negeri 1 DermajiKecamatan Banyumas Kabupaten Banyumas; (2) Penggunaan metode STAD terbukti dapat meningkatkan hasil belajar siswa di kelas IV SD Negeri 1 DermajiKecamatan Banyumas Kabupaten Banyumas.
\end{abstract}

Kata kunci: Metode STAD, Motivasi dan Hasil Belajar Siswa.

\begin{abstract}
The purpose of this study was (1) to analyze the impact of using the Student Team Achievement Division (STAD) method to increase student motivation about the concept of calculating the area of a triangle in class IV SD Negeri 1 Dermaji, Lumbir District, Banyumas Regency. (2) analyzing the impact of using the Student Team Achievement Division (STAD) method can improve student learning outcomes about the concept of calculating the area of a triangle in class IV SD Negeri 1 Dermaji Banyumas District Banyumas Regency. The CAR procedure consists of four steps of research, namely planning, implementation, observation and reflection in its implementation of two cycles. The results of this study can be concluded as follows: (1) the use of the STAD method in mathematics learning about calculating the area of a triangle can increase learning motivation of fourth grade students of SD Negeri 1 Dermaji Banyumas District Banyumas Regency with an increase from 10 students to 22 students or $50.00 \%$. (2) With the use of visual aids can improve student learning outcomes in class IV SD Negeri 1 Dermajid with an average from the beginning of learning to the second cycle that is 49.79 to 75.63 increased 86.67 and mastery learning from 8 students to 18 students later rose to 23
\end{abstract}


students from 24 students overall. So in the conclusion of this study are (1) The use of the STAD method can increase student motivation in class IV SD Negeri 1 Dermaji Banyumas District Banyumas Regency; (2) The use of the STAD method is proven to be able to improve student learning outcomes in class IV SD Negeri 1 Dermaji, Banyumas District, Banyumas Regency.

Keywords: STAD Method, Motivation and Student Learning Outcomes.

\section{PENDAHULUAN}

Pembelajaran Matematika mempunyai tujuan untuk membentuk kemampuan berpikir siswa yang tercermin melalui kemampuan berpikir kritis, logis, sistematis, dan memiliki sikap yang objektif, jujur, disiplin, dalam memecahkan masalah dalam bidang matematika maupun bidang lain dalam kehidupan sehari-hari. Namun pada kenyataannya matematika merupakan pelajaran yang dianggap paling sulit dan menjadi hal yang paling menakutkan sehingga banyak siswa yang mengeluh jika mendapat mata pelajaran ini. Berdasarkan hasil observasi di kelas IV SD Negeri 1 Dermajiditemukan bahwa banyak siswa yang belum dapat memahami konsep menghitung luas segitiga dengan baik. Hal ini ditunjukkan dengan data hasil belajar siswa kelas IV SD Negeri 1 Dermajipada ulangan harian, menunjukkan bahwa rata-rata nilai yang dicapai terendah adalah mata pelajaran Matematika dengan Kriteria Ketuntasan Minimal (KKM) yaitu 60. Dari 24 siswa, ada 8 siswa $(33 \%)$ yang memperoleh nilai di atas Kriteria Ketuntasan Minimal (KKM) dan ada 16 siswa (67\%) yang nilainya masih di bawah Kriteria Ketuntasan Minimal (KKM). Kondisi ini menyebabkan peneliti ingin memperbaiki pembelajaran Matematika khususnya pada materi menghitung luas segitiga. Untuk lebih jelasnya peneliti sampaikan Analisis Hasil Tes Formatif di bawah ini :

Tabel 1 Hasil Tes Formatif Menghitung Luas Segitiga Kelas IV SD Negeri 1 Dermaji UPK Lumbir

\begin{tabular}{|c|c|c|c|c|}
\hline No & Nilai & Frekuensi & Prosentase & Keterangan \\
\hline 1. & $20-29$ & 6 & $25 \%$ & Tidak Tuntas \\
2. & $30-39$ & 1 & $4,17 \%$ & Tidak Tuntas \\
3. & $40-49$ & 4 & $16,67 \%$ & Tidak Tuntas \\
4. & $50-59$ & 5 & $20,83 \%$ & Tidak Tuntas \\
5. & $60-69$ & 5 & $20,83 \%$ & Tuntas \\
6. & $70-79$ & 1 & $4,17 \%$ & Tuntas \\
7. & $80-89$ & - & - & - \\
8. & $90-99$ & - & - & - \\
9. & 100 & 2 & $8,33 \%$ & Tuntas \\
\hline
\end{tabular}

Untuk mengatasi masalah tersebut maka alternatif pemecahan dapat dipresentasikan dalam pembelajaran STAD (Student Team Achievement Division). Dalam metode STAD 
siswa ditempatkan dalam kelompok belajar beranggotakan empat atau lima orang yang merupakan campuran menurut kinerja, jenis kelamin, dan suku. Metode STAD lebih menekankan pada kegiatan belajar kelompok, dimana siswa secara aktif melakukan diskusi, kerja sama, saling membantu, dan semua anggota kelompok mempunyai peran dan tanggung jawab yang sama. Dengan metode ini diharapkan motivasi dan hasil belajar siswa pada mata pelajaran Matematika pada konsep menghitung luas segitiga kelas IV SD Negeri 1 DermajiUPK Lumbir meningkat.

Kajian teori dalam penelitian ini sebagaimana dipaparkan dalam uraian berikut. Kata motivasi berasal dari bahasa latin " movere" yang artinya menimbulkan pergerakan. Motivasi didefinisikan sebagai kekuatan psikologis yang menggerakkan seseorang kearah beberapa jenis tindakan (Haggard, 1989) dan sebagai suatu kesediaan peserta didik untuk menerima pembelajaran, dengan kesiapan sebagai bukti dari motivasi (Redman, 1993). Munurut Kort (1987), motivasi adalah hasil faktor internal dan faktor eksternal dan bukan hasil eksternal saja. Hal yang tersirat dari motivasi adalah gerakan untuk memenuhi suatu kebutuhan atau mencapai suatu tujuan. Motivasi juga didefinisikan sebagai dorongan dari dalam diri individu berdasarkan mana dari berperilaku dengan cara tertentu untuk memenuhi keinginan dan kebutuhannya. Adapun pemotivasian dapat diartikan sebagai pemberian motif-motif sebagai pendorong agar orang bertindak, berusaha untuk mencapai $\begin{array}{llll}\text { tujuan } & \text { organisasional } & \text { (Silalahi,2002). }\end{array}$ (http://tkampus.blogspot.com/2012/04/pengertian-motivasi-dan-teori-teori-html) Robbins dan Judge (2007) mendefinisikan motivasi sebagai proses yang menjelaskan intensitas, arah dan ketekunan usaha untuk mencapai suatu tujuan. Belajar adalah proses perubahan perilaku akibat interaksi individu dengan lingkungan. Jadi perubahan perilaku adalah hasil belajar artinya seseorang telah dikatakan belajar jika ia dapat melakukan sesuatu yang tidak dapat dilakukan sebelumnya. (Drs. Lukmanul Hakim,M.Pd dalam Perencanaan Pembangunan 2008 :277). Menurut Daryanto (2010:2) dalam (http:www.sarjanaku.com/ 2011/03/pengertian -definisi- hasil-belajar. html) belajar adalah suatu proses usaha yang dilakukan seseorang untuk memperoleh suatu perubahan tingkah laku yang baru secara keseluruhan, sebagai hasil pengalamannya sendiri dalam interaksi dengan lingkungannya. Sedangkan menurut Djamarah (2008:13) mengatakan bahwa belajar adalah serangkaian kegiatan jiwa raga untuk memperoleh suatu perubahan tingkah laku sebagai hasil dari pengalaman individu dalam interaksi dengan lingkungannya yang menyangkut kognitif, afektif, dan psikomotor. 
Pengertian belajar yang cukup komprehensif diberikan oleh Bell-Gredler (1985:1) yang menyatakan belajar adalah proses yang dilakukan oleh manusia untuk mendapatkan aneka ragam competencies, skill and attitude. Kemampuan (Competencies), keterampilan (Skill), dan sikap ( Attitude ) tersebut diperoleh secara bertahap dan berkelanjutan mulai dari bayi sampai masa tua melalui rangkaian proses belajar sepanjang hayat. Rangkaian proses belajar itu dilakukan dalam bentuk keterlibatannya dalam pendidikan informal, keturutsertaannya dalam pendidikan formal dan atau pendidikan non formal. Kemampuan ini yang membedakan manusia dari makhluk lainnya. Matematika adalah simbol ilmu deduktif yang tidak menerima pembuktian secara induktif, ilmu tentang pola keteraturan, dan struktur yang terorganisasi dari unsur yang tidak didefinisikan ke unsur yang dapat didefinisikan ke postulat dan selanjutnya ke dalil. (Ruseffendi dalam Heruman,2007 : 1). Menurut Jonson dan rising dalam Aji Apriyanto (http.//www. Ajiapriyanto .co.cc. html) Matematika adalah pengetahuan struktur yang terorganisasi, sifat-sifat atau teori dibuat secara deduktif berdasarkan pada unsur yang didefinisikan aksioma teori yang dibuktikan kebenarannya. Dengan kata lain Matematika merupakan suatu bahasa yang dilukiskan dengan bilangan atau simbol tertentu yang didefinisikan dengan cermat dan jelas. Dari pendapat para ahli di atas dapat disimpulkan bahwa matematika adalah pengetahuan yang tersusun secara sistematis yang dilukiskan dengan bilangan dengan bilangan atau simbol tertentu yang didefinisikan dengan cermat dan jelas untuk memecahkan masalah yang berhubungan dengan bilangan.

Pengertian Metode STAD (Student Team Achievement Division) Menurut Slavin (2009 : 12), gagasan utama dari metode STAD adalah untuk memotivasi siswa supaya dapat saling mendukung dan membantu satu sama lain dalam menguasai kemampuan yang diajarkan oleh guru. Dalam metode STAD siswa ditempatkan dalam kelompok belajar beranggotakan empat atau lima orang yang merupakan campuran menurut kinerja, jenis kelamin, dan suku. Metode STAD lebih menekankan pada kegiatan belajar kelompok, dimana siswa secara aktif melakukan diskusi, kerja sama, saling membantu, dan semua anggota kelompok mempunyai peran dan tanggung jawab yang sama. Menurut Slavin (2009 : 143) metode STAD adalah salah satu metode pembelajaran yang paling sederhana, dan merupakan metode yang paling baik bagi para guru yang baru menggunakan pembelajaran kooperatif. Menurut Isjoni (2009 : 74) STAD merupakan salah satu tipe kooperatif yang menekankan pada adanya aktifitas dan interaksi diantara siswa untuk saling memotivasi dan saling membantu dalam menguasai materi pelajaran guna mencapai prestasi yang maksimal. Slavin (2009:141) berpendapat metode STAD merupakan metode 
yang digunakan secara terstruktur, metode STAD merupakan metode yang terdapat dalam pembelajaran kooperatif yang paling tua dan paling banyak digunakan dalam penelitian pendidikan, termasuk juga dalam penyampaian materi di kelas. Komponen Metode STAD Menurut Slavin (2009:143-160), metode STAD terdiri dari lima komponen utama yaitumPresentasi Kelas. Materi dalam metode STAD adalah pengenalan awal dalam presentasi kelas. Dalam presentasi kelas ini, guru mengajarkan materi secara langsung dalam pertemuan kelas. Tim (Tahap Kerja Kelompok).

Kelompok terdiri dari 4-5 siswa yang mempunyai karakteristik yang berbeda-beda atau heterogen baik dalam penguasaan materi, jenis kelamin, maupun keturunan. Fungsi utama dari kelompok adalah memastikan bahwa semua anggota kelompok dapat belajar dan juga untuk mempersiapkan anggota kelompok dalam menghadapi tes. Kuis (Tes Individu). Setelah kurang lebih 1-2 pertemuan dari presentasi guru dan 1-2 kali kelompok melakukan latihan dalam kelompoknya, siswa diberi tes individu. Siswa tidak boleh saling membantu selama tes. Jadi setiap siswa bertanggung jawab secara individu dalam menguasai materi pembelajaran yang telah diberikan. Hasil selanjutnya diberi skor. Skor Kemajuan Individual, Maksud dari skor kemajuan individual adalah memberikan nilai pada setiap siswa yang dapat dicapai jika mereka bekerja keras dan mengerjakan lebih baik dari pada materi yang telah lampau. Rekognisi Tim Setelah melakukan kuis, perhitungan skor perkembangan individu dan skor kelompok dilakukan. Skor individu setiap anggota kelompok memberikan sumbangan pada skor kelompok berdasarkan skor pada kuis sebelumnya dengan skor kuis terakhir. Indikator keberhasilan untuk mengukur peningkatan hasil belajar siswa adalah ketuntasan siswa dalam mempelajari materi pelajaran. Sisw dinyatakan tuntas belajar jika telah mencapai tingkat penguasaan materi pelajaran $85 \%$ ke atas. Indikator yang digunakan untuk mengukur peningkatan keaktifan belajar siswa adalah keterlibatan siswa secara aktif dalam proses pembelajaran. Siswa dinyatakan terlibat secara aktif jika:

1. Siswa mau mengajukan dan menjawab pertanyaan

2. Siswa bekerja secara mandiri

3. Siswa aktif belajar dan bekerja dalam kelompok

4. Siswa akif dalam mengkomunikasikan hasil.

Kriteria yang digunakan untuk mengukur tingkat keberhasilan perbaikan pembelajaran adalah sebagai berikut:

1. Intervensi yang dilakukan dikatakan mampu meningkatkan motivasi belajar siswa jika minimal $85 \%$ siswa menampilkan satu dari dua indikator yang dipersyaratkan. 
2. Intervensi yang dilakukan dikatakan dapat meningkatkan hasil belajar siswa jika ada peningkatan hasil belajar siswa serta minimal $85 \%$ dari jumlah siswa tuntas belajar.

\section{HASIL DAN PEMBAHASAN}

Siklus I

Setelah intervensi dilakukan, terjadi perubahan yang berarti pada siklus 1 sebagaimana tergambar dalam hasil di bawah ini

a) Pada sebelum perbaikan, nilai rata-rata kelas 49,79 setelah dilakukan perbaikan mengalami kenaikan menjadi 75,63. Rata-rata kelas naik 25,84.

b) Pada siklus I siswa yang tuntas belajar sebanyak 18 siswa dari 24 siswa (75\%) dengan nilai rata-rata 75,63 .

c) Ada 20 siswa yang mengalami kenaikan nilai prestasi yaitu 25,84 .

Pada tahap pengamatan diperoleh data sebagai berikut:

Tabel 2 Rekapitulasi Motivasi Siswa dalam Mengikuti Pembelajaran pada Siklus I

\begin{tabular}{|c|c|c|c|}
\hline No & Pembelajaran & $\begin{array}{c}\text { Siswa yang benar-benar telah } \\
\text { menunjukkan motivasi belajar }\end{array}$ & Persentase \\
\hline 1 & Sebelum perbaikan Siklus I & 10 & 41,67 \\
2 & Sesudah perbaikan siklus & 18 & 75,00 \\
\hline
\end{tabular}

Dari tabel di atas dapat diperoleh keterangan sebagai berikut:

a) Sebelum perbaikan, siswa yang benar-benar telah menunjukkan motivasi belajar sebanyak 10 siswa atau 41,67\%.

b) Pada siklus I, siswa yang benar-benar telah menunjukkan motivasi belajar sebanyak 18 siswa atau $75,00 \%$.

c) Dari sebelum perbaikan ke siklus I, motivasi belajar siswa naik 33,33\%.

Hasil Belajar Matematika

Tabel 3 Hasil Belajar Matematika pada Siklus I

\begin{tabular}{|c|c|c|c|c|}
\hline No & Nilai & Frekuensi & Prosentase & Keterangan \\
\hline 1. & $20-29$ & - & - & Tidak Tuntas \\
2. & $30-39$ & 1 & $4,17 \%$ & Tidak Tuntas \\
3. & $40-49$ & 2 & $8,33 \%$ & Tidak Tuntas \\
4. & $50-59$ & 3 & $12,50 \%$ & Tidak Tuntas \\
5. & $60-69$ & 2 & $8,33 \%$ & Tuntas \\
6. & $70-79$ & 2 & $8,33 \%$ & Tuntas \\
7. & $80-89$ & 4 & $16,67 \%$ & Tuntas \\
8. & $90-99$ & 7 & 29,17 & Tuntas \\
9. & 100 & 3 & $12,50 \%$ & Tuntas \\
\hline
\end{tabular}

Dari tabel di atas dapat diperoleh keterangan sebagai berikut: 
a) Sebelum perbaikan, siswa yang benar-benar telah menunjukkan hasil belajar di atas KKM sebanyak 8 siswa atau $33,33 \%$.

b) Pada Siklus I, siswa yang benar-benar telah menunjukkan hasil belajar di atas KKM sebanyak 18 siswa atau $75,00 \%$.

c) Dari sebelum perbaikan ke siklus I, hasil belajar siswa naik 41,67\%.

\section{Siklus II}

Hasil siklus 2 dapat diperoleh keterangan sebagai berikut:

a) Pada siklus I nilai rata-rata kelas 75,63. Setelah dilakukan perbaikan dengan mengakomodasikan kelemahan pada siklus I, nilai rata-rata kelas pada siklus II mengalami kenaikan menjadi 86,67. Nilai rata-rata kelas naik menjadi 11,04 dari siklus I atau 36,88 dari sebelum perbaikan.

b) Pada siklus II, siswa yang tuntas belajar sebanyak 23 siswa dari 24 siswa atau 95,83\% dengan nilai rata-rata $86,67$.

c) Ada 22 siswa yang mengalami kenaikan nilai prestasi yaitu 91,67\%.

Pengamatan

Motivasi Belajar Siswa

Pada hasil pengamatan siklus II diperoleh data sebagai berikut:

Tabel 5 Rekapitulasi Perbandingan Motivasi Siswa dalam Mengikuti Pembelajaran pada Siklus I dan Siklus II.

\begin{tabular}{|c|c|c|c|}
\hline No & Pembelajaran & $\begin{array}{c}\text { Siswa yang benar-benar telah } \\
\text { menunjukkan motivasi belajar }\end{array}$ & Persentase \\
\hline 1 & Sebelum perbaikan Siklus I & 10 & 41,67 \\
3 & Siklus II & 18 & 75,00 \\
3 & 22 & 91,67 \\
\hline
\end{tabular}

Dari tabel diatas diperoleh keterangan sebagai berikut:

a. Pada siklus I, siswa yang benar-benar telah menunjukkan motivasi belajar sebanyak 18 siswa atau $75,00 \%$.

b. Pada siklus II, siswa yang benar-benar telah menunjukkan motivasi belajar sebanyak 22 siswa dari 24 siswa atau 91,67\%.

c. Dari siklus I ke siklus II, motivasi belajar siswa naik 16,67 atau 50,00 dari sebelum perbaikan.

Hasil Belajar Siswa 
Tabel 6 Hasil Belajar Maematika pada Siklus II

\begin{tabular}{|c|c|c|c|c|}
\hline No & Nilai & Frekuensi & Prosentase & Keterangan \\
\hline 1. & $20-29$ & - & - & Tidak Tuntas \\
2. & $30-39$ & - & - & Tidak Tuntas \\
3. & $40-49$ & - & - & Tidak Tuntas \\
4. & $50-59$ & 1 & $4,17 \%$ & Tidak Tuntas \\
5. & $60-69$ & 4 & $16,67 \%$ & Tuntas \\
6. & $70-79$ & - & - & Tuntas \\
7. & $80-89$ & 4 & $16,67 \%$ & Tuntas \\
8. & $90-99$ & 6 & $25,00 \%$ & Tuntas \\
9. & 100 & 9 & $37,50 \%$ & Tuntas \\
Jumlah & & 24 & $100 \%$ & \\
\hline
\end{tabular}

Dari tabel di atas dapat diperoleh keterangan sebagai berikut:

a) Pada Siklus I, siswa yang benar-benar telah menunjukkan hasil belajar di atas KKM sebanyak 18 siswa atau 75,00\%.

b) Pada Siklus II, siswa yang benar-benar menunjukkan hasil belajar di atas KKM sebanyak 23 siswa atau $95,83 \%$.

c) Dari Siklus I ke Siklus II, hasil belajar siswa naik 20,83\%.

Penggunaan Metode Student Team Achievement Division (STAD) dapat meningkatkan motivasi belajar siswa pada konsep menghitung luas segitiga kelas IV SD Negeri 1 DermajiUPK Lumbir Kabupaten Banyumas. Altenatif pemecahan masalah untuk mengatasi rendahnya penguasaan siswa terhadapmateri dan motivasi belajar siswa maka pembelajaran dengan menggunakan metode STAD ternyata memberikan motivasi belajar yang signifikan jika dibandingkan dengan sebelum perbaikan. Pada awal pembelajaran motivasi siswa sebesar $41,67 \%$ dan pada siklus I sebesar $75,00 \%$ sehingga mengalami kenaikan dalam motivasi belajar siswa sebesar 33,33\%. Hal ini seperti yang dikatakan Krapp, Hidi dan Reemninger (dalam Lestari,dkk,2007:3.5) Keaktifan merupakan dorongan dalam diri seseorang atau faktor yang menimbulkan ketertarikan atau perhatian secara selektif yang menyebabkan dipilihnya suatu obyek yang menguntungkan, menyenangkan dan lama-kelamaan akan mendatangkan keaktifan dan kepuasan bagi dirinya. Lebih lanjut (Lestari,dkk,2007 : 3.7) mengatakan "seorang anak tidak lahir dengan meminta tertentu." Keaktifan berkembang melalui pengalaman belajar. Sorang guru harus menumbuhkan keaktifan anak didik agar perkembangan keaktifannya sejalan dengan meluasnya cakrawala berfikir anak. Intervensi yang peneliti lakukan dengan mengimplementasikan peraga model sehingga menimbulkan ketertarikan bagi siswa yang berimplitasi pada keaktifan siswa dapat berkolerasi positif dengan meningkatnya motivasi belajar siswa. 


\section{KESIMPULAN}

Berdasarkan hasil analisis data dan temuan yang diperoleh pada perbaikan pembelajaran Matematika tentang menghitung Luas Segitiga di SDN 1 DermajiUPK Lumbir Kabupaten Banyumas yang telah dilaksanakan dan berdasarkan hasil pengamatan peneliti dan dibantu Observer serta Supervisor, dapat diambil kesimpulan sebagai berikut:

1. Penggunaan metode STAD dapat meningkatkan motivasi belajar siswa SD Negeri 1 DermajiUPK Lumbir Kabupaten Banyumas, dari 10 siswa menjadi 22 siswa atau naik $50,00 \%$.

2. Penggunaan metode STAD terbukti dapat meningkatkan hasil belajar siswa kelas IV pada mata pelajaran Matematika tentang menghitung luas segitiga. Hal ini ditunjukkan oleh temuan pada studi awal siswa yang tuntas baru 8 siswa dari 24 siswa atau 33,33\%, siklus I mencapai 18 siswa atau 75,00\%, siklus II mencapai 23 siswa atau $95,83 \%$.

\section{SARAN}

Perlu dilakukan penelitian di semua mata pelajaran terkait penerapan metode STAND

\section{DAFTAR PUSTAKA}

Anggoro Toha,dkk.2011. Metode Penelitian. Jakarta : Universitas Terbuka.

Handoko Tri.2006. Terampil Matematika 4. Jakarta : Yudhistira.

http:/ktiptk.blogspirit.com/archieve/2009/01/26/Pengertian Metode.html.

I.G.A.K. Whardani,dkk.2010. Penelitian Tindakan Kelas. Jakarta : Universitas Terbuka.

Jhonson dan Rising dalam Aji Apriyanto (http.///www.Aji Apriyanto.co.cc.html)

Mustaqim Burhan dan Ary Astuti.2008. Ayo Belajar Matematika Untuk SD dan MI Kelas IV. Jakarta : Cempaka Putih.

Sudrajat Ahmad.2008. http://akhmadsudrajat.wodpress.com/2008/02/06/teori-teori-motivasi/

Sugiyanto.2008.Model-model Pembelajaran Inovatif. Surakarta : Panitia sertivikasi Guru PSG Rayon 13.

Taniredja Tukiran,dkk.2011. Model-model Pembelajaran Inovatif dan Efektif. Purwokerto : Alfabeta.

Tim Bina Karya Guru.2007. Terampil Berhitung Matematika untuk SD Kelas IV. Jakarta : Erlangga.

Tim Kurikulum.2011. Standar Kompetensi Kelas IV. Jakarta : Departemen Pendidikan Nasional. 